\title{
A tribute to John Rosselli
}

John Rosselli was little more than a name to me until I met him at a Risorgimento conference in Mantua around 1980. I of course knew he was the son of the Carlo Rosselli whom Mussolini had had murdered in 1937, but it is only from obituaries that I have learned of his childhood and early life in Paris and the USA before he came to live in England after the war. I knew too that he had been a PhD student at Peterhouse, Cambridge under Butterfield and had won the Thirlwall Prize for his admirable work on Bentinck in Sicily. I now know that, working for the Manchester Guardian in the 1950s and early 1960s, he was first its literary editor and then features editor. He also became its conscience, urging it to emulate the more intellectual newspapers of the Continent rather than the Daily Telegraph. His frustration with the newspaper's change of character moved him to apply for a lectureship at the new University of Sussex where, from 1964 to 1989, he taught broadly and successfully, did much committee work, was appointed to a readership, wrote on Bentinck in India, began editing his father's papers and turned to the history of opera.

When he retired to Cambridge, he came to most of the seminars on modern European history, where I got to know him. At the seminars his comments were never overbearing, even when his knowledge could have blown the speaker out of the water. I recall one occasion when a pretty good but inevitably rather detached paper was given by a young student about a French fascist newspaper of the 1930s. John asked a benign question, but it was based on his perhaps unique recollections of reading the newspaper concerned as a boy in Paris. He would offer acute advice and fundamental criticism in a matter-of-fact tone that could not be resented.

He was extraordinarily broad in his culture, familiar with the major European literatures, equally widely read in history and with an extensive and profound knowledge of music. One wishes that he had written more on the history of Italy because when he spoke about it he showed not only deep knowledge but remarkable objectivity. This was perhaps his most striking characteristic. His penetrating, lucid and logical mind led him to shy away from panache and rhetoric. He did not enter into the heady Italian nationalism evident in such contexts as Risorgimento congresses and standard patriotic histories. I never saw him obviously deeply stirred, probably because I did not know him well enough. But one sensed in him a determined reserve.

He had reviewed opera for the Guardian for decades and in the 1980s began writing about the social history of Italian opera. The result was two splendid books, the first, The Opera Industry in Italy from Cimarosa to Verdi (Cambridge University Press, 1984) was mainly concerned with the impresarios, their methods and their importance for society and for the operas. The second, Singers of Italian Opera (Cambridge University Press, 1992), broader in period and scope, contains highly original material, for example, on the training, pay and careers of singers and on the importance of the Church's music, musical education and opportunities for opera singers, male and female. A striking discussion of the castrati places them in a context of populous monasteries and 
widespread celibacy, offering an explanation of their existence and their attitudes that only he had the range of knowledge to justify. Massive research in scattered and difficult archives was presented with economy, elegance and wit. There followed three short lives of Bellini (1996), Mozart (1998) and Verdi (2000) (all published by Cambridge University Press: all his books, I am told, reached the publisher before the contract date). This unassumingly presented oeuvre constitutes a major contribution to the history of opera and to the social history of Italy.

We may be sure that his comparatively early death at the age of 73 has deprived us of a good deal more. But he will be remembered as a man with a high sense of integrity and responsibility and as a scholar, writer and journalist of astonishing intellectual range and capacity.

Derek Beales University of Cambridge 